\title{
THE RELATIONSHIP BETWEEN FINANCIAL EFFICIENCY RATIOS AND STOCK PRICES: AN EMPIRICAL INVESTIGATION ON INSURANCE COMPANIES LISTED IN BORSA ISTANBUL
}

\author{
Rafet AKTAŞ ${ }^{*}$ \\ Seyfettin ÜNAL ${ }^{* *}$
}

\begin{abstract}
It is a common perception that efficiency is an important issue regardless of industry. A sound and highly functional insurance industry serves as a crucial financing channel in an economy. At this aspect, this study aims to examine the relationship between the financial efficiency ratios and stock prices of insurance firms, whose stocks are publicly traded in Borsa Istanbul. The study is performed on quarterly data set. The sample period covers 2005Q1 and 2012Q4. Taking three sets of efficiency ratios, which are namely cost, revenue and profit efficiency, as proxy, we run a regression analysis against stock prices. This study is the first, best to our knowledge, in examining the interaction between Turkish insurance firms' efficiency ratios and their stock prices. Our findings suggest that all of employed models confirm statistically significant relationships between the ratios and stock prices. Among the three ratio groups, profitability ratios emerge as the best fit models. The results carry important implications for insurance firms as well as investors.
\end{abstract}

Keywords: Insurance, Efficiency, Ratios

Jel Codes: C10, C22, G22

\section{FINANSAL ETKİNLİK ORANLARI VE HİSSE SENEDİ FİYATLARI ARASINDAKİ İLIŞKİ: BORSA ISTANBUL'DA İŞLEM GÖREN SİGORTA ŞİRKETLERİ ÜZERİNE AMPİRIK BİR ARAŞTIRMA}

Öz

Hangi sektörde olursa olsun etkinliğin önemli bir konu olduğu genel kabul gören bir anlayıştır. İyi işleyen sağlıklı bir sigortacılık sektörü bir ekonomi için hayati bir finansman kanalı işlevini görecektir.

Associate Professor of Accounting at Yildirim Beyazit University of Turkey raktas@ybu.edu.tr

Associate Professor of Finance at Dumlupinar University of Turkey; and is the corresponding author seyfettinu@hotmail.com 
Buradan hareketle bu çalışma, hisseleri Borsa İstanbul'da işlem gören sigorta şirketlerinin hisse senedi fiyatları ile finansal etkinlik oranları arasındaki ilişkiyi incelemeyi amaçlamaktadır. Çalışma çeyrek dönemlik veriler üzerinde yürütülmüştür. Örneklem dönemi 2005 Ç1 ve 2012Ç4 arasını içermektedir. Maliyet, gelir ve kârlılık etkinliği olmak üzere üç grup etkinlik oranları ölçü alınarak hisse senedi fiyatlarına karşı bir regresyon analizi gerçekleştirilmiştir. Bilindiği kadarıyla, Türkiye'deki sigorta firmalarının etkinlik oranları ve hisse senedi fiyatları arasındaki ilişkiyi incelemesi itibariyle çalışma literatürde bir ilki temsil etmektedir. Ulaşılan bulgular uygulanan bütün modellerde oranlar ve hisse fiyatları arasında istatistiksel olarak anlamlı ilişkilerin varlığına işaret etmektedir. Söz konusu üç oran grubundan en güçlü modellerin, kârlılık oranları olduğu görülmüştür. Bulgular sigorta şirketlerinin yanı sıra yatırımcılar açısından da önemli sonuçlar içermektedir.

Anahtar Kelimeler: Sigorta, Etkinlik, Oranlar

Jel Kodları: C10, C22, G22

\section{INTRODUCTION}

Insurance industry plays a pivotal role in an economy by creating funds for investments, which promotes economic growth. Therefore, having a sound and growing insurance industry is highly crucial especially in developing economies. Despite this fact, only limited number of studies can be observed on these countries' insurance industries. Insurance firms provide a wide range of services for policyholders. Among these are financial planning, risk management, and the provision of legal defense in liability disputes. For life insurance companies, financial intermediation is a principal function, which is achieved by selling asset accumulating products like annuities. For non-life insurers, intermediation is an important but incidental service, which derives from premium collection prior to claim payments. Insurance firms' value-added from intermediation is shown in the net interest margin between the rate of return on invested assets and the rate credited to policyholders. In order to maximize the shareholder wealth, insurance firms are required to be operated efficiently. This efficiency may come from profit maximization as well as cost minimization or a combination of the two. Efficiency of insurance industry has been the focus of many scholars in recent literature. Nevertheless, the output is typically intangible hence difficult to measure and control for financial services firms such as banks and insurers. Therefore, the pragmatic technique is to identify the services provided by such firms and to find measurable proxies that are quite correlated with these services. It is well known that insurance firms carry unique features. They differ from manufacturing firms even from other financial services companies thus the legal systems also treat them differently. Insurance companies gain their earnings today against their unknown future liabilities. This reverse earning-cost relationship results in a complex structure. Therefore, it requires sophisticated approaches in evaluating financial performance of insurance firms.

In spite of its considerably low share in the financial system of Turkey, Turkish insurance industry possesses a significant growth potential in the near future. The main focus of this 
paper is to empirically investigate the relationship between firm-specific financial variables and stock prices in the Turkish stock market. By doing this, we aim to consider the individual and incremental significance of the economic determinants of stock prices. If a statistical connection is identified between the efficiencies and stock prices, this would account for an alternative explanation of share price fluctuations. This, in turn, would enhance the relevance and value of research in insurance firms' efficiencies to investors, stock analysts and the regulators. The sample, covering the period of 2005-2012, consists of quarterly data set of seven publicly traded insurance companies. This study differs from the previous literature as it is first, to our knowledge, in examining the Turkish insurance firms' efficiency ratios and their impact on stock prices. Results of the study are expected to help insurance firms to take necessary operational steps towards improving efficiency as well as to provide investors with useful insights in making investment decisions. The rest of the paper is organized as follows: the second section includes some outline information about the current outlook of Turkish insurance industry. The literature review is provided in the third section. The fourth section contains data and methodology. Following the empirical findings in the fifth section, the paper completes with the conclusion section.

\section{THE CURRENT OUTLOOK OF THE TURKISH INSURANCE MARKET}

It may be clearly stated that the development of insurance industry in an economy is highly correlated with the general socio-economic maturity level of that economy. As a result of increasing wealth in emerging economies during the last few decades, their insurance industries have shown a considerable growth. This trend, as expected, reflects in the scholar works that there is a growing body of literature on the insurance industries of these countries.

Following the country-specific financial crisis of 2001, Turkey's insurance industry enjoyed a considerable growth until 2008. During the last global financial crisis; however, a decline has been observed in the industry. According to Insurance Supervision Board (2012) data, by the end of 2012, there are 59 insurance and pension fund companies in the marketplace. Out of these 59 companies, the number of non-life insurers is 35 while the number of life and, life and pension fund companies is 6 and 17 respectively. In addition, there is also 1 reinsurance company in the industry. Only 7 insurance companies's stocks are publicly traded in Borsa Istanbul.

The number of non-life insurance companies with foreign capital investment is 28 while the same figure for life insurance segment is 16 . In 37 of these 44 insurers, the foreign ownership capital is $50 \%$ or more. In Turkey, non-life insurance premium dominates the market and substantially exceeds the life insurance. In 2012, a total of 19.8 billion Turkish liras (about $\$ 10$ billion) premium produced. When the premium production is examined with respect to nonlife and life/pension insurance, it is seen that the share of non-life companies increased to $84 \%$ in 2012. Low penetration rate and the growth potential continue to draw attention of foreign investors to the Turkish insurance market. While there were only 15 companies with international share in 2001, this number reached to 44 in 2011 and decreased to 43 in 2012. By the end of 2012, 25 of 35 non-life insurance companies and 18 of 23 life and pension companies have direct or 
indirect international capital. The share of international capital is $50 \%$ or above in 35 companies (Insurance Supervision Board, 2012). All these figures reflect the insufficiency in current position of Turkish insurance industry as well as the prosperous potential in its future. This, in turn, also explains the growing interest of multinational insurers by their recent entrance into the market.

\section{LITERATURE REVIEW}

Recently, insurance industry has become an attractive topic among scholars. The subject owes its popularity mostly to increasing income in developing economies. The increase in wealth results in an enormous rise in demand for insurance. This, in turn, stimulates the potential in the insurance industry.

In reviewing the related literature, it may be meaningful to look at the studies by dividing them into two different groups. In the first sub-title, we provide a summary of efficiency studies on financial services firms in general and insurance firms more specifically. The second sub-title includes studies involved with financial ratios, which is the main interest of our research.

\section{I. Efficiency in Financial Services Industry}

With respect to studies on developed economies' insurance markets, an earlier one is notably carried out by Cummins and Weiss (1993) on the US insurance market. They conduct an efficiency analysis on a sample of property-liability insurers over the period of 1980-1988. Their study measures the efficiency by estimating stochastic cost frontiers for three size-stratified samples of multiple line insurers, and comparing actual insurer operating cost to the frontiers. They report wider variations in efficiency for small and medium-size insurers compared to large insurers. They argue that small and medium-size insurers are characterized by economies of scale, suggesting a cost reduction potential by mergers/acquisitions (M\&A) within the industry. Moreover, their results imply that small and medium-size insurers may be under-producing loss adjustment services; however, large firms may be over-producing this output.

Cummins et.al. (2010) also investigate the US insurance industry over the period of 19932006. The study questions whether it is better for insurers to provide both life-health and property-liability insurance services or to focus on one main industry branch. They estimate cost, revenue and profit efficiency by employing data envelopment analysis (DEA) and test for scope economies. The results imply that insurance companies should focus on core businesses instead of following conglomeration strategies.

Similar to studies of Cummins and Weiss (1993) and of Cummins et.al. (1998), Diacon et.al. (2002) investigate the effect of insurers' size on efficiency via cross-country comparisons. Using staff and capital resources as the main inputs and premiums and investment income as the main outputs, the study analyzes the average efficiency of insurance companies licensed in 15 European countries over the period of 1996-1999. The results reveal that very large or very small insurers 
are likely to be the most efficient ones in pure technical terms. In addition, the insurers operating in the UK, Spain, Sweden, and Denmark are likely to show highest average level of technical efficiency. Lastly, compared to their European rivals, the insurers of UK seem to produce low levels of scale and mix efficiency.

In a cross-country study, Fernandez et.al. (2002) examine the economic efficiency of 142 financial intermediaries from eighteen countries for the period 1989-1998 and the relationship between efficiency, productivity change and shareholders' wealth maximization by applying DEA. After estimating the relative efficiency of commercial banks of different geographical areas, they carry out a Malmquist decomposition in order to separate efficiency change from technical change. Their examination of the relationship between economic efficiency and wealth maximization reflects different productivity patterns among three geographical areas (North America, Japan and Europe), indicating that the estimates of economic efficiency and productivity changes are consistent with the wealth maximization criterion.

Applying DEA, Kirkwood and Nahm (2006) examine the cost efficiency of Australian banks. In the study, they report an improved efficiency in the major banks despite little change in the efficiency of ragional banks. With respect to the relation between the measured changes in efficiency and stock returns, their results reveal that stock returns reflect efficiency changes.

In addition to examining the relative cost and profit efficiencies of a panel of six Singaporelisted banks by employing DEA, Chu \& Lim (1998) also investigate the existence of a statistical relationship between efficiency scores and how the shares of the banks performed in the marketplace. They find that percentage changes in the prices of the bank shares reflect percentage changes in profit rather than cost efficiencies.

Abidin and Cabanda (2011) test the efficiency performance of non-life insurers in Indonesia during the period of 2005-2007. Their results gathered from the DEA measurement show that bigger insurance firms appeared to have a higher efficiency score compared to their smaller counterparts. Their findings also confirm that, except for net premium margin (NPM); no significant associations are exist between the value of DEA, return on assets (ROA), and return on equity (ROE). This implies that an increase in NPM results in a total efficiency increase.

Employing the cost efficiency method after Tone (2002), Sinha and Chatterjee (2009) investigate the cost efficiency of life insurance industry of India over two-year sub-sample periods between 2002 and 2007. The results of their analysis suggest an upward trend in cost efficiency on the sample of life insurance firms over the sub-sample periods of 2002-2003 and 2004-2005. On the other hand, the analysis shows a reverse trend for other two-year periods of 2005-2006 and 2006-2007.

Barros and Obijiaku (2007) conduct both a technical and a scale efficiency analyses on a sample of Nigerian insurance firms for the period of 2001-2005. Utilizing the DEA method, they reach to conclude that large insurers produce higher efficiency scores than small insurers. As another finding, the study implies that insurance companies managed by a bank network tend to have higher efficiency scores compared to those not managed by a bank network. Lastly, the 
analysis reveals that insurers with higher market share operate more efficiently compared ones with lower market share.

There is also a limited number of studies on insurance market efficiency of Turkey, which is the interest of this study. Among these studies, Kilickaplan and Karpat (2004), Ciftci (2004), Kayali (2007), Turkan et.al. (2012), Turgutlu et.al. (2007), and Kasman and Turgutlu (2009) can be named. In one of them, Ciftci (2004) analyzes the efficiency of Turkish insurance companies. The study is performed under two separate groups, namely life and non-life insurers by applying the DEA technique. The results reveal that only 11 of 41 non-life insurance companies operate efficiently. With respect to the life insurance companies, only 3 out of 12 find to be efficient.

By employing Tobit Model, Kilickaplan and Karpat (2004) analyze the technical, scale and pure efficiency of Turkish life insurance companies over the period of 1998-2002. Their results indicate that the number of companies is negatively correlated with technical efficiency while it is positively correlated with scale efficiency. In the year of 1999, when Turkey was hit by two major earthquakes, insurance companies experienced a drop in both technical and scale efficiency. Finally, insurance premiums show a positive relationship with all three efficiency measures.

Kayali (2007) evaluates the technical, pure technical and scale efficiency of Turkish insurance companies during the period of 2000-2006 by using DEA and Malmquist total factor productivity (TFP) index. An increase in the efficiency scores of insurance firms in Turkey is observed for the study period. The technical efficiency of Turkish insurance companies is also evaluated by Turgutlu et.al. (2007). In this study, the researchers examined the technical efficiency of non-life insurance firms by adopting both conventional and chance-constrained DEA over the period of 1990-2004.The results indicate a meaningful efficiency problem in Turkey's non-life insurance companies for the study period.

Using the Malmquist TFP index, Kasman and Turgutlu (2009) analyze the TFP change in life and non-life branches of Turkish insurance industry over the period of 2000-2005. They conduct the analysis on two groups of companies by separating them with respect to ownership structure as domestic and foreign. The findings suggest a drop in total factor productivity for both groups in life insurance branch. However, the total factor productivity improves in non-life branch only for domestic insurance firms.

Cagil and Karabay (2010) evaluate the financial performance of 25 non-life insurance companies in Turkey. Using DEA methodology, the study aims to provide information of insurance industry's performance over the period of 2003-2008. The study reaches comparatively higher efficiency scores for the sample companies. Finally, Turkan et.al. (2012) investigate the technical efficiency of non-life insurance companies in Turkey. The empirical results of their Banker-Charnes-Cooper (BCC) and Charnes-Cooper-Rhodes (CCR) models reveal Ray as the most effective of 23 insurance companies in the sample.

\subsection{Financial Ratios and Efficiency}

Although ratios seem to be somehow instable across different industries and time periods, they also appear to be indispensable. Therefore, financial ratios are commonly used for modelling 
purposes both by practitioners and researchers and are considered at least a starting point for analysis. A business firm involves many such interested parties as shareholders, management, personnel, customers, suppliers, competitors, regulatory agencies, and academics. Each of these have their own unique interest hence views in applying financial statement analysis in their evaluations. Despite that financial analysis dates back, the use of financial ratios is fairly new, owing to the advances in the accessibility of financial data that become readily available by digital technology. The technology has also offered modern data processing techniques and statistical packages to ease and speed up data handiling procedure.

Horrigan (1983) suggests that financial ratio research should be more interested in the role of the financial ratios themselves than in "the nature of the ratios' components or to the ratios' incidental role as data size deflators". Based on Horrigan's critique, Salmi \& Martikainen (1994) interprete that the validity of financial ratio analysis should be determined by its usefulness to the decision making process of the different interested parties such as owners, management, creditors and personnel.

The research on the functional form of financial ratios has been characterized by theoretical discussions about the ratio format in financial ratio analysis and empirical testing of the ratio model. McDonald and Morris $(1984,1985)$ provide the first extensive empirical studies on the statistical validity of the financial ratio methodology. Though they find support for financial ratio analysis for comparisons within industry groups, the same is not valid for comparisons between different industries.

Despite that the empirical interdependencies of financial ratios have been extensively studied in the literature, they have not generally been related to stock markets until recently. As Martikainen (1993) points out, in empirical studies, the relationships between stock returns and financial characteristics have been rather studied on single ratio level.

Martikainen (1993) asserts that a financial variable collected from financial statements of a firm is defined to be an individually significant economic determinant of stock returns if it has a significant association with this stock market based variable. It is also stated that this is true if the selected financial variable represents a significant proportion of the information set which the market uses when determining stock returns. In addition, when studying the incremental information of financial variables, the main issue is whether different financial variables have incremental information content beyond that contained in the individually most significant financial characteristics of a firm. If it is not the case, a decision maker should focus merely on the most important ratios rather than analyze a wide number of different ratios. Therefore, Martikainen (1993) questions whether different financial variables are essentially substitutes for one to another in this context. And, he finds that the marginal utility of evaluating a large number of different financial ratios may be quite low. Alternatively, decision makers might be better off by concentrating in a relatively low number of key financial ratios.

Literature that relates efficiency and stock market data involves, at certain degree, market efficiency through price discovery process. This is a legitimate argument since there are huge number of studies that stand at least for the weak-form of market efficiency. On this ground, 
efficiency measures are calculated based on published accounting numbers which are publicly known information. Thus, in a stock market with at least certain degree of efficiency, such public information is presumably reflected in the prices.

In a pioneer study of the field, Martikainen (1993) analyzes the relationship between stock returns and financial ratios by a regression analysis. His results shows that none of the single financial ratios possess incremental information about stock returns in Finnish stock market. Another outcome of the study is the weak relationship between betas and financial ratios. The researcher attributes this to the high estimation errors in betas, problems of measuring the true market portfolio and inefficiency of the Finnish stock market.

Using financial ratios, Davis \& Peles (1993) examine the total adjustment over time and then assess both the relative adjustment speed and the relative weights of industry and management. Their results indicate that firms' liquidity ratios, EPS ratios have a fast adjustment to equilibrium values while performance measures have a relatively long adjustment process to equilibrium values. In addition to findings that the adjustment rates differ for different industries, they also report that smaller firms adjust their ratios to the optimal target more quickly than the large ones. Finally, the researchers' tests of the predictive power of their model show that information about the existence of equilibrium ratios and their adjustment speeds can help predict future values or events, and identify firms in special categories, for example, firms that will be acquired.

Applying several variables as proxy for the capital structure decision of each firm and share price as proxy for value, Chowdhury \& Chowdhury (2010) conduct a panel data work with aiming to find out the impact of capital structure on the value of a firm in Bangladesh. The implication revealed from their study is that a firm can increase its value in the market by altering its capital structure composition.

In another study, Pasiouras et.al. (2008) investigate the Greek banking efficiency and relates it with the share performance. Their regression analysis of the stock returns and efficiency changes indicate a positive and statistically significant relationship between technical efficiency changes and stock returns, while the analysis report no impact of changes in scale efficiency on stock returns.

Following the work of Diacon et.al. (2002), Ajlouni and Tobaishat (2010) aim to identify the relationship between stock price and the efficiency of insurance firms in Jordan. The sample covers 22 insurance companies listed in Amman Stock Exchange (ASE) over the period of 20002006. The researchers apply a simple regression analysis in order to investigate the relationship between stock price (as the dependent variable) and technical efficiency score (as the independent variable). Their study also reveals the degree at which the stock price is affected by the technical efficiency score. The results suggest that the efficiency of sample insurance firms shows an increase over the period. In addition, the stock market realizes and rewards the increases in technical efficiency of insurance companies by reflecting in their stock prices. Therefore, there is a positively significant relationship exists between the stock prices of insurance companies and their technical efficiency scores. 
As a related sample study over the Turkish market, Aydemir et.al. (2012) also employ a panel data analysis in order to find out the relationship between the financial ratios and stock prices of non-financial firms. Their findings provide that liquidity ratios, profitability ratios and leverage ratio, interestingly, have positive impact on stock returns. Nonetheless, operational ratios carry no impact on stock returns. The researchers conlude that financial ratios have a relatively weak role in predicting stock returns.

\section{DATA and METHODOLOGY}

Stock prices of financial services firms are considered as a leading indicator of whole economy since they not only contain the firm-specific data but also possess indirect data from firms of other industries. This derives from the fact that credit linkage provides a close relationship with every aspect of macro-economy regardless of sector or geography. Due to their inter-relations with each segment of the economy, the behavior of financial service firms' stock prices is assumed to carry highly valuable information. This argument is also attributable to shares of insurance firms at certain degrees. At this point, we should note that stocks of financial services firms weigh relatively high in the indices of Borsa Istanbul. Financial services firms' stocks are currently account for about $52 \%$ of BIST National Index.

There are 7 insurance companies listed in Borsa Istanbul and; our study sample covers all of them. The list of these companies can be seen in table 1 . The analysis is conducted on quarterly data for the period between 2005Q1 and 2012Q4. The limitation regarding our data set derives from the fact that despite the study covers all public insurance companies, there are only seven publicly traded insurance firms in Borsa Istanbul. The sample data set is gathered from audited unconsolidated financial statements of the insurance companies. The financial statements as well as the stock prices of companies are obtained from Public Disclosure Platform and Borsa Istanbul. The goal of the study is to measure the cost, revenue, and profit efficiency and to test the connection between these efficiency ratios and stock prices of all seven publicly traded insurance companies in Borsa Istanbul. Our choice of variables is determined in part by the desire for a practical model and in part by the smallness of our data set.

Table I. Sample Insurance Companies and Their Ticker Symbols

\begin{tabular}{|c|l|l|}
\hline & \multicolumn{1}{|c|}{ Ticker } & \multicolumn{1}{c|}{ Company Name } \\
\hline 1 & AKGRT & AKSIGORTA \\
\hline 2 & ANSGR & ANADOLU SIGORTA \\
\hline 3 & ANHYT & ANADOLU HAYAT EMEKLILIK \\
\hline 4 & AVIVA & AVIVA SIGORTA \\
\hline 5 & GUSGR & GUNES SIGORTA \\
\hline 6 & RAYSG & RAY SIGORTA \\
\hline 7 & YKSGR & YAPI KREDI SIGORTA \\
\hline
\end{tabular}


Covering the years between 2005 and 2012, the efficiency analysis is performed on 7 companies that are continuously traded during the sample period. Computed on quarterly data set of 2005-2012, three commanly used efficiency ratios are chosen as proxy under each efficiency group. The ratios under each efficiency set are provided on table 2. As a result, we obtain 32 ratios for each of seven insurance firms for the whole period. This yields to a total of 224 observations to be included in the analysis, which is conducted in the second part of the study. In the literature of evaluating insurance industry's performance, various financial ratios have been used. Despite admitting the fact that financial ratios contain useful information, some literature claims this measure to be inadequate for performance evaluation. Even though we are aware that the use of financial ratios may cause certain weaknesses in the analysis, the limitations regarding our data set leave us with not many options.

Table 2. Efficiency Ratios

\begin{tabular}{|c|l|}
\cline { 2 - 3 } \multicolumn{1}{c|}{} & \multicolumn{1}{c|}{ Cost Efficiency Ratios } \\
\hline ce1 & Technical Allowances / Total Assets \\
\hline ce2 & Technical Expenses / Net Premiums Collected \\
\hline ce3 & Investment Expenses / Net Premiums Collected \\
\hline \multicolumn{1}{c|}{ Revenue Efficiency Ratios } \\
\hline re1 & Net Premiums Collected / Total Assets \\
\hline re2 & Net Premiums Collected / Technical Allowances \\
\hline re3 & Investment Income / Total Assets \\
\hline pe1 & Net Profit / Total Assets \\
\hline pe2 & Technical Profit / Total Assets \\
\hline pe3 & Technical Profit / Technical Income \\
\hline
\end{tabular}

Next, we aim to identify the relationship between the efficiency ratios and the stock price. To serve the purpose, a regression analysis is conducted by taking the efficiency ratios as explanatory variables and the stock price as dependent variable. The efficiency ratios are regressed against stock prices as in Chu and Lim (1998) and Ajlouni and Tobaishat (2010). Different from these studies; however, we used quarterly closing stock prices. Based on the fact that accounting data are revealed with about one quarter lag, the stock price data we employ in the analysis match the announcement date of financial information rather than the term the financial data belong to. The regression equations for each group are, 
$\mathrm{P}_{\mathrm{t}}=\beta_{0}+\beta_{1} \mathrm{~V}_{\mathrm{t}(\mathrm{cel}-3)}+\mathrm{u}_{\mathrm{t}}$

(1)

$\mathrm{P}_{\mathrm{t}}=\beta_{0}+\beta_{1} \mathrm{~V}_{\mathrm{t}(\mathrm{rel}-3)}+\mathrm{u}_{\mathrm{t}}$

(2)

$\mathrm{P}_{\mathrm{t}}=\beta_{0}+\beta_{1} \mathrm{~V}_{\mathrm{t}(\mathrm{pel}-3)}+\mathrm{u}_{\mathrm{t}}$

where, $P_{t}$ is the stock price, $V_{t(c e l-3)}$ is the cost efficiency ratios, $V_{t(\text { rel-3) }}$ stands for revenue efficiency ratios, and $\mathrm{V}_{\mathrm{t}(\mathrm{pel}-3)}$ represents profit efficiency ratios.

\section{EMPIRICAL FINDINGS}

Table 3 shows the results of the regression analysis in which the cost efficiency ratios are explanatory variable and stock price is the dependent variable.

Table 3. Results of the Regression Analysis between Cost Efficiency Ratios and Stock Price

\begin{tabular}{|c|c|c|c|c|c|c|c|}
\hline Ratios & Constant & $t$-test & $\mathrm{Ce}$ & $t$-test & $\mathbf{R}^{2}$ & $F$-test & $\begin{array}{c}\text { Number of } \\
\text { observations }\end{array}$ \\
\hline cel(model I) & 3.01 & $3.41^{* * *}$ & 4.45 & $2.76^{\star * *}$ & 0.03 & $7.61^{\star * \star}$ & 32 \\
\hline ce2(model II) & 7.95 & $6.57^{* * *}$ & 2.40 & $2.28^{\star *}$ & 0.02 & $5.18^{\star *}$ & 32 \\
\hline ce3(model III) & 3.96 & $6.73^{* * *}$ & -16.58 & $-2.70^{* * *}$ & 0.03 & $7.30^{* * *}$ & 32 \\
\hline
\end{tabular}

The model 1 (ce1) employs technical allowances to total assets ratio as the explanatory variable for stock price. The coefficient of this ratio is 4.45 and $t$-test suggests that it is statistically significant at $1 \%$ level. Despite that the model's explanatory power is $3 \%$ only, $F$-statistic of 7.61 confirms the validity of the model at $1 \%$ conventional level. In the model 2 (ce2), technical expenses to net premiums collected ratio is the explanatory variable of stock price. The coefficient forecast of the ratio is 2.4 , which is statistically significant at $5 \%$ level. The model's R-square is $2 \%$ and $F$-test value (5.18) is statistically significant at $5 \%$ level. The third model (ce3) in the cost efficiency ratio group uses investment expenses to net premiums collected as the explanatory variable. The model reveals a coefficient of -16.58 , which is statistically significant at $1 \%$. While the model's explanatory power is $3 \%, F$-test takes the value of 7.3 , suggesting statistical significance at $1 \%$ level.

Table 4 reports the results of the regression models for revenue efficiency ratios. Model 4 
employs the ratio of net premiums collected to total assets as the explanatory variable. In this model, the coefficient is 4.96 and statistically significant at $1 \%$ level. The model has an R-square of $6 \%$ and an F-statistic of 13.32 , which is statistically significant at $1 \%$. Net premiums collected to technical allowances ratio is taken as the independent variable in model 5 , which produces a coefficient of 1.91 that is statistically significant at $5 \%$ level. The model's R-square is $3 \%$ while its $F$-statistic is statistically significant at $5 \%$ level. The model 6 considers the ratio of investment income to total assets as explanatory variable. The model reflects a coefficient of 64.54 , which is statistically significant at $1 \%$. The model has an R-square of $14 \%$ and an F-test of 34.66 , statistically significant at $1 \%$ level.

Table 4. Results of the Regression Analysis between Revenue Efficiency Ratios and Stock Price

\begin{tabular}{|c|c|c|c|c|c|c|c|}
\hline Ratios & Constant & $t$-test & $\operatorname{Re}$ & $t$-test & $\mathbf{R}^{2}$ & $F$-test & $\begin{array}{l}\text { Number of } \\
\text { observations }\end{array}$ \\
\hline re1(model IV) & 3.59 & $6.41^{\star * *}$ & 4.96 & $3.65^{\star \star \star}$ & 0.06 & $13.32^{* * *}$ & 32 \\
\hline re2(model V) & 4.00 & $6.57^{\star * *}$ & 1.91 & $2.50^{\star \star}$ & 0.03 & $6.27^{\star \star}$ & 32 \\
\hline re3(model VI) & 2.83 & $5.50^{\star * *}$ & 64.54 & $5.89^{\star * \star}$ & 0.14 & $34.66^{\star * *}$ & 32 \\
\hline
\end{tabular}

Table 5 presents the findings of the regression analysis conducted to identify the relationship between profit efficiency ratios and stock price.

Table 5. Results of the Regression Analysis between Profit Efficiency Ratios and Stock Price

\begin{tabular}{|c|c|c|c|c|c|c|c|}
\hline Ratios & Constant & $\boldsymbol{t}$-test & Pe & $\boldsymbol{t}$-test & $\mathbf{R}^{2}$ & $\boldsymbol{F}$-test & $\begin{array}{c}\text { Number of } \\
\text { observations }\end{array}$ \\
\hline pe1(model VII) & 4.95 & $16.12^{* * *}$ & 50.99 & $5.71^{* * *}$ & 0.13 & $32.63^{* * *}$ & 32 \\
\hline pe2(model VIII) & 5.09 & $16.93^{* * *}$ & 58.10 & $6.05^{* * *}$ & 0.14 & $36.64^{* * *}$ & 32 \\
\hline pe3(model IX) & 5.12 & $16.58^{* * *}$ & 18.62 & $4.84^{* * *}$ & 0.10 & $23.40^{* * *}$ & 32 \\
\hline$* * *$ statistically significant at $1 \%$ level.
\end{tabular}

In the model 7, net profit to total assets ratio is run as the explanatory variable of the stock price. The both showing statistical significance, a coefficient of 50.99, and an F-statistic of 32.63 
are reached. The model's R-square is $13 \%$. The model 8 employs technical profit to total assets ratio as the independent variable. The model produces outcomes in which the R-square is $14 \%$, the coefficient is 58.10 , and the $F$-statistic is 36.64 . They are statistically significant at $1 \%$ level. Finally, the ratio of technical profit to technical income ratio is assigned as the explanatory variable in the model 9. This model also results in statistically significant (at $1 \%$ level) $t$ and $F$ test values. The model has a coefficient of 18.62, and an R-square of $10 \%$. The results of the analysis suggest that 7 out of 9 models we employ are fit and statistically significant at $1 \%$ level. The exceptions are the model 2 and 5, which are also statistically significant yet at 5\% level. As in similar studies, expectedly lower values of R-squares refer the existence of explanatory variables other than ratios employed in the models. Overall, we may conclude that there is a statistically significant relationship between stock prices and selected efficiency ratios of the insurance companies.

Publicly traded companies are presumably larger ones compared to those not publicly traded. Based on this, our findings are also similar to those of Chowhury\&Chowhury (2010), Ajlouni and Tobaishat (2010), Ismail et.al. (2011) and Aydemir et.al. (2012). It is also worth noting that future studies on Turkish insurance industry may provide useful insights by investigating the efficiency subject from other perspectives such as conglomeration strategies, M\&A and comparisons of small-medium-large insurers.

\section{CONCLUSION}

Insurance industry provides an important function in an economy by creating funds for investments, which eventually fosters economic growth. Therefore, having a well-functioning insurance industry growing at its full potential is highly preferable especially in developing economies. Nonetheless, only limited number of studies can be observed on these countries' insurance industries.

Like any other businesses, insurance firms are expected to utilize their resources efficiently in order to promote shareholders' wealth. This efficiency may come from profit maximization as well as cost minimization or a combination of the two. An insurance firm is considered technically efficient if it can reduce the use of inputs without any corresponding reduction in output, providing the current state of production technology in the industry.

As well as any other businesses, insurance companies are required to be operated efficiently in order to maximize their market value. In spite of its considerably low share in the financial system, Turkish insurance industry possesses a significant growth potential in near future. The Turkish insurance industry is a relatively competitive market. This study aims to identify the relationship between stock prices and efficiency of insurance companies listed in Borsa Istanbul. For the purpose, we conduct a regression analysis. Efficiency of insurance industry has been the focus of many scholars in recent literature. The connection between profitability indicators and stock returns has been widely studied (eg. Hamada, 1969 and 1972; Bhandari, 1988; Fewings, 1975; Martikainen, 1993) and these studies mostly report the close relationship between them. Since 
they report that the technical efficiency of insurance companies has weak effect on stock price, Ajlouni and Tobaishat (2010) suggest that future studies should concentrate on other variables that may influence stock price such as financial ratios. Following their suggestion, we conduct an analysis on the relationship between efficiency ratios and stock prices of insurance firms. This study differs from the previous literature as it is first, best to our knowledge, in examining the relationship between Turkish insurance firms' efficiency and their stock prices.

Covering the years between 2005Q1 and 2012Q4, we performed the research on all of 7 companies whose stocks are continuously traded in Borsa Istanbul during the sample period. As the efficiency indicators, we employ three groups of ratios namely cost, revenue and profit efficiency ratios. Next, we investigate the relationship between the efficiency ratios of insurance companies and their stock prices. Despite the lower R-squares, which is the case expectedly quite normal, the models are fit and statistically significant. The findings suggest that there is a statistically significant relationship between efficiency ratios and stock price. These results are also in line with the similar studies by Chowhury \& Chowhury (2010), Ajlouni and Tobaishat (2010), Ismail et.al. (2011) and Aydemir et.al. (2012). Results of the study are expected to help insurance firms to take necessary operational steps towards improving efficiency as well as to provide investors with useful insights in making investment decisions. 


\section{References}

ABIDIN, Zaenal and CABANDA, Emilyn (2011), "Efficiency of Non-Life Insurance in Indonesia”, Journal of Economics, Business and Accountancy Ventura, 14(3), pp.197-202.

AJLOUNI, Moh'd M. and TOBAISHAT, Sinan (2010), "The Effect of Technical Efficiency in Insurance Companies on Stock Performance: Data Envelopment Analysis (DEA) Evidence from Jordanian Companies Listed in Amman Stock Exchange (ASE) During the Period (2000-2006)", International Journal of Strategic Management, 10(1), Available from http://www.freepatentsonline.com/article/ International-Journal-Strategic-Management/ 237305845.html [Accessed 21 March 2013].

AYDEMIR, Oguzhan, OGEL, Serdar \& DEMIRTAS, Gokhan (2012), "Hisse Senedi Fiyatlarının Belirlenmesinde Finansal Oranların Rolu”, Yonetim ve Ekonomi: Celal Bayar Universitesi, 19(2), pp.277-288.

BARROS, Carlos Pestana and OBIJIAKU, Echika Lemechi (2007), “Technical Efficiency of Nigerian Insurance Companies", School of Economics and Management, Technical University of Lisbon, Department of Economics, Working Papers, WP/018/2007/DE/UECE, pp.1-32.

BHANDARI, Laxmi Chand (1988), "Debt/Equity Ratio and Expected Common Stock Returns: Empirical Evidence", Journal of Finance, 63(2), pp.507-528.

CAGIL, Gulcan and KARABAY, Melisa Erdilek (2010), "An Implementation towards the Evaluation of Financial Performance in Turkish Insurance Sector at Global Crises Scale", International Journal of Economics and Finance Studies, 2(1), ISSN: 1309-8055 (Online).

CHU, Sing Fat and LIM, Guan Hua (1998), "Share Performance and Profit Efficiency of Banks in an Oligopolistic Market: Evidence from Singapore”, Journal of Multinational Financial Management, 8, pp.155-168.

CHOWDHURY, Anup and CHOWDHURY, Suman Paul (2010), "Impact of Capital Structure on Firm's Value: Evidence from Bangladesh”, Business and Economic Horizons, 3(3), pp.111-122.

CIFTCI, Hakkı (2004), “Turk Sigorta Sektorunun Sorunlari, DEA Analizi ile Turk Sigorta Sirketlerinin Etkinlik Duzeylerinin Belirlenmesi”, Cukurova Universitesi Sosyal Bilimler Enstitusu Dergisi, 13(1), pp.121-149.

CUMMINS, J. David, WEISS, Mary A., XIE, Xiaoying and ZI, Hongmin (2010), "Economies of Scope in Financial Services: A DEA Efficiency Analysis of the US Insurance Industry", Journal of Banking and Finance, 34(7), pp.1525-1539.

CUMMINS, J. David, WEISS, Mary A. (1993), "Measuring Cost Efficiency in the Property-Liability Insurance Industry", Journal of Banking and Finance, 17, pp.463-481.

CUMMINS, J. David, TENNYSON, Sharon and WEISS, Mary A. (1998), "Consolidation and Efficiency in the U.S. Life Insurance Industry", Federal Reserve Bank of Philadelphia Working Papers, 98-18.

DAVIS, Harry Zvi and PELES, Yoram C. (1993), "Measuring Equilibrating Forces of Financial Ratios", The Accounting Review, 68(4), pp.725-747.

DIACON, S. R., STARKEY, K. and O’BRIEN, C. (2002), "Size and Efficiency in European Long-Term Insurance Companies: An International Comparison", The Geneva Papers on Risk and Insurance, 27(3), pp.444-466.

FERNANDEZ, Ana Isabel, GASCON, Fernando \& GONZALEZ, Eduardo (2002), "Economic Efficiency and Value Maximization in Banking Firms", The $7^{\text {th }}$ European Workshop on Efficiency and Productivity Analysis.

FEWINGS, David R. (1975), “The Impact of Corporate Growth on the Risk of Common Stocks", Journal of Finance, 30(2), pp.525-531. 
HAMADA, Robert S. (1969), "Portfolio Analysis, Market Equilibrium and Corporate Finance”, Journal of Finance, 24(1), pp.13-32.

HAMADA, Robert S. (1972), "The Effect of the Firm's Capital Structure on the Systematic Risk of Common Stock”, Journal of Finance, 26(2), pp.425-452.

HORRIGAN, James O. (1983), "Methodological Implications of Non-Normally Distributed Financial Ratios: A Comment", Journal of Business Finance and Accounting, 10(4), pp.683-689.

INSURANCE SUPERVISION BOARD, (2012), Insurance and Private Pension Activities, Insurance Supervision Board of Turkish Republic Prime Ministry Under Secretary of Treasury. Annual Report 2012.

ISMAIL, Norashikin, ALHABSHI, Syed Othman and BACHA, Obiyathulla (2011), "Cost Efficiency and Investment Performance: Mutual and Stock Form in Malaysian Insurance Industry”, Working paper, International Centre for Education in Islamic Finance (INCEIF). Available from http://www. wbiconpro.com/355-Norashikin.pdf [Accessed 23 April 2013].

KASMAN, Adnan and TURGUTLU, Evrim (2009), “Total Factor Productivity in the Turkish Insurance Industry”, International Journal of the Economics of Business, 16(2), pp.239-247.

KAYALI, Cevdet Alptekin (2007), “2000-2006 Doneminde Turkiye'de Faaliyet Gosteren Sigorta Sirketlerinin Etkinlik Degerlendirmesi”, Yonetim ve Ekonomi: Celal Bayar Universitesi, 14(2), pp.103-115.

KILICKAPLAN, Serdar and KARPAT, Gaye (2004), “Turkiye Hayat Sigortasi Sektorunde Etkinligin Incelenmesi”, DEU IIBF Dergisi, 19(1), pp.1-14.

KIRKWOOD, Joshua and NAHM, Daehoon (2006), "Australian Banking Efficiency and and Its Relation to Stock Returns", The Economic Record, 82(258), pp.253-267.

MARTIKAINEN, Teppo (1993), "Stock Returns and Classification Pattern of Firm-Specific Financial Variables: Empirical Evidence with Finnish Data”, Journal of Business Finance \& Accounting, 20(4), pp.537-557.

McDONALD, Bill and MORRIS, Michael H. (1984), “The Statistical Validity of the Ratio Method in Financial Analysis: An Empirical Examination”, Journal of Business Finance and Accounting, 11(1), pp.89-97.

McDONALD, Bill and MORRIS, Michael H. (1985), “The Functional Specification of Financial Ratios: An Empirical Examination”, Accounting and Business Research, 15(59), pp.223-228.

PASIOURAS, Fotios, LIADAKI, Aggeliki \& ZOPOUNIDIS, Constantin (2008), "Bank Efficiency and Share Performance: Evidence from Greece", Applied Financial Economics, 18, pp.1121-1130.

SALMI, Timo and MARTIKAINEN, Teppo (1994), "A Review of the Theoretical and Empirical Basis of Financial Ratio Analysis", The Finnish Journal of Business Economics, 4(94), pp.426-448.

SINHA, Ram Pratap and CHATTERJEE, Biswajit (2009), "Are Indian Life Insurance Companies Cost Efficient?", Electronic copy available at SSRN: http://dx.doi.org/10.2139/ssrn.1391904 [Accessed 22 May 2013].

TONE, Kaoru (2002), "A Strange Case of the Cost and Allocative Efficiencies in DEA", Journal of the Operational Research Society, 53, pp.1225-1231.

TURGUTLU, Evrim, KOK, Recep and KASMAN, Adnan (2007), “Turk Sigortacılık Sirketlerinde Etkinlik: Deterministik ve Sans Kisitlı Veri Zarflama Analizi”, Iktisat Isletme ve Finans, 22(251), pp.85-102.

TURKAN, Semra, POLAT, Esra and GUNAY, Suleyman (2012), “The Efficiency Analysis of Non-Life Insurance Companies Active in Turkey", Zagreb International Review of Economics and Business, 15(2), pp.1-14. 